\title{
Monitoring defecation activity of infaunal deposit feeders ${ }^{*}$
}

\author{
Fred C. Dobbs** \\ Marine Research Laboratory, The University of Connecticut, P. O. Box 278, Noank, Connecticut 06340, USA
}

\begin{abstract}
An inexpensive, reliable thermistor device capable of monitoring infaunal foraging activity was built and used in the laboratory to examine effects of temperature on sediment reworking by the maldanid polychaete Clymenella torquata. The worm defecated at least once per hour $55.0 \%$ $\left(12.0^{\circ} \mathrm{C}\right)$ to $88.2 \%\left(5.5^{\circ} \mathrm{C}\right)$ of the time. Defecation rate was linearly and positively related to temperature. Estimated volume of sediment ejected per defecation $(0.015 \mathrm{ml})$ did not change with temperature. Results are compared with previous reworking studies of $C$. torquata.
\end{abstract}

\section{INTRODUCTION}

Many of the effects which deposit-feeding benthos exert on the physical, chemical, and biological properties of sediments are mediated by their feeding activity (e.g. Pryor, 1975; Goldhaber et al., 1977; Yingst and Rhoads, 1978; Baumfalk, 1979; Aller, 1980; Anderson, 1980; Eckman et al., 1981; Hammond, 1981; Nowell et al., 1981). Therefore, detailed knowledge of depositfeeding ecology is of interest. Although techniques exist to monitor the feeding behavior of tubicolous infauna (e.g. Wells, 1953; Mangum, 1964a; Kudenov, 1978), methodological limitations commonly prevent long-term, undisturbed records of organism activity. In this paper a relatively inexpensive, reliable thermistor device for monitoring infaunal foraging activity is described. Data examining sediment reworking rates by the maldanid polychaete Clymenella torquata in relation to temperature are presented and compared to previously published estimates.

\section{MATERIALS AND METHODS}

Bioturbation was monitored using a flowmeter modified from LaBarbera and Vogel (1976). Matched hot bead thermistors (Fenwal Electronics GB32P38, 2000

\footnotetext{
- Contribution No. 156 from The University of Connecticut Marine Sciences Institute, USA

- Present address: Institut for Genetik og Økologi, Aarhus Universitet, Aarhus C, DK-8000, Denmark.
}

$\mathrm{Ohm} \pm 1 \%, 2.54 \mathrm{~mm}$ in diameter, stub ends glass encapsulated) formed arms of a bridge circuit (Fig. 1). Remaining components were fixed resistors $(0.25 \mathrm{~W}$ rating, $5 \%$ tolerance) and an operational amplifier (741). The bridge was connected to the op-amp using Fairchild linear integrated circuits. Power was supplied by a standard op-amp power supply. Circuit output was recorded by connecting a potentiometric strip chart recorder between the amplifier and the negative side of the bridge. To waterproof the thermistor probes, their leads were soldered to 26 gauge wire, the wire was threaded through glass tubing, and tubing and stub end of thermistor were joined and sealed with shrink tubing. The glass tubing then was placed through bored corks and held by clamps attached to a ring stand.

The apparatus was used to examine temperature effects on defecation rates of Clymenella torquata. This polychaete lives anterior end down in a vertically positioned sand tube and ingests sediments 10 to $15 \mathrm{~cm}$ below the sediment surface. To defecate, the worm moves upward to its tube opening and ejects unconsolidated feces onto the adjacent sediment surface (Mangum, 1964a, b; Rhoads, 1967). Adult worms (ca. $5 \mathrm{~cm}$ long) were collected from a shallow subtidal sand flat and maintained at a naturally occurring population density (ca. $700 \mathrm{~m}^{-2}$; Dobbs, 1981) in laboratory sediment microcosms (plastic basins $28 \times 31 \times 13 \mathrm{~cm}$ deep). Microcosms were held in running ambient seawater at least one week prior to any measurements. New microcosms were established with freshly collected worms for experiments at $18.0^{\circ} \mathrm{C}$ 


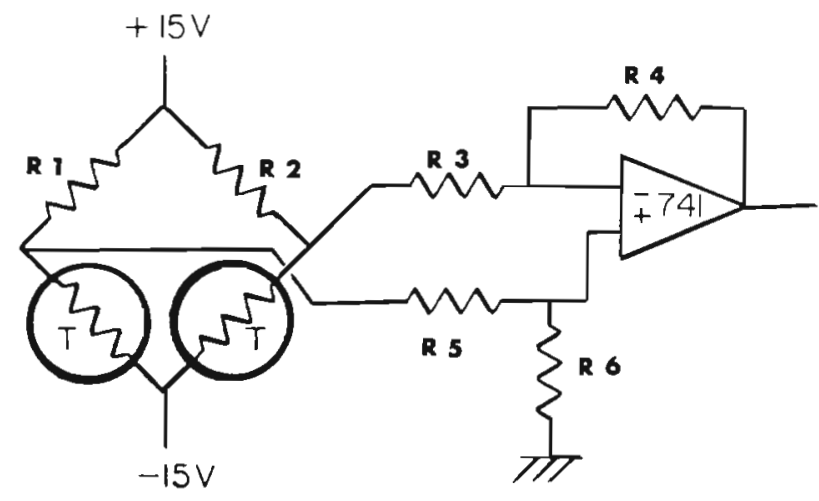

Fig. 1. Clymenella torquata. Schematic diagram of flowmeter used to monitor defecation episodes. $\mathrm{T}=$ thermistor $; \mathrm{R} 1$ and $\mathrm{R} 2$ are $2.15 \mathrm{~K} \Omega$; all other resistors are $1 \mathrm{M} \Omega ; 741=$ operational amplifier

(June, 1978 ), $12.0^{\circ} \mathrm{C}$ (November, 1978), and $5.5^{\circ} \mathrm{C}$ (January, 1979). Microcosm sediment temperatures were isothermic with the overlying water and fluctuated less than $1.0 \mathrm{C}^{\circ}$ during each experiment. Experiments generally lasted $24 \mathrm{~h}$, although activity patterns over $88 \mathrm{~h}$ were obtained. After each set of measurements, the microcosm was examined for tubes curved at their lower end, i.e. the head shaft, a condition which may occur if the sediment is too shallow (Mangum, $1964 \mathrm{~b}$; pers. obs.). In all cases, only straight tubes were found.

To record worm activity, one probe (the sensing thermistor, $T_{s}$ ) was positioned in the water over an individual worm's tube opening. A plastic collar $(3.5 \mathrm{~cm}$ in diameter, height sufficient to reach to the air-water interface) was placed on the sediment surrounding the worm's tube. The collar thus enclosed $\mathrm{T}_{\mathrm{s}}$ and greatly reduced signal interference caused by water flow in the experiments. The other probe (the compensating thermistor, $\mathrm{T}_{\mathrm{T}}$ ) was positioned within a collar in an area of the microcosm containing no worms. Worm activity moved water past $\mathrm{T}_{\mathrm{s}^{\prime}}$ cooling it relative to the undisturbed $T_{I}$, and the resistance change was translated as a deflection on the recorder. Each of the worm's defecations caused a spike on the trace baseline (Fig. 2). Worm feces were collected using methods modified from Rhoads (1967) and Gordon (1966) and measured volumetrically (relationship between volume in $\mathrm{ml}[\mathrm{X}$ ] and dry weight in $\mathrm{g}[\mathrm{Y}]$ was $\mathrm{Y}=1.26 \mathrm{X}-0.07, \mathrm{r}=0.99, \mathrm{n}=21$ ). Mean volume of material per defecation was calculated by dividing total volume of sediment defecated by each worm by number of defecations indicated on its trace.

Data were examined for differences among temperatures using a non-parametric Kruskal-Wallis test (alpha $=0.05$ ). If results were significant, then values were compared with the a posteriori Duncan's multiple range test, corrected for unequal sample sizes.

\section{RESULTS}

Analysis of nearly $500 \mathrm{~h}$ of records indicated that Clymenella torquata defecated at least once per hour $67.6 \%\left(18.0{ }^{\circ} \mathrm{C}\right), 55.0 \%\left(12.0^{\circ} \mathrm{C}\right)$, and $88.2 \%\left(5.5^{\circ} \mathrm{C}\right)$ of the time (Table 1). Time spent reworking, i.e. percent defecation hours, was significantly lower at $12.0^{\circ} \mathrm{C}$ than at $5.5^{\circ} \mathrm{C}$. Due to large variability, there were no differences among temperatures in the duration of defecation activity periods (DAP), quiescence periods (QP), nor in the number of defecations per defecation activity period (refer to table legend for definitions). Defecation rate at $5.5^{\circ} \mathrm{C}$ was significantly lower than at $18.0^{\circ} \mathrm{C}$ and $12.0^{\circ} \mathrm{C}$. There was a positive, linear relationship between temperature $\left({ }^{\circ} \mathrm{C}\right)(\mathrm{X})$ and number of defecations per hour (Y): $\mathrm{Y}=0.16 \mathrm{X}+1.47$. $\mathrm{r}=0.74, \mathrm{n}=21$. Estimated volume of sediment ejected per defecation was $0.015 \mathrm{ml}$ ( $\mathrm{n}>1100$ defecations) and cid not change with temperature, suggesting that a threshold volume of sediment must accumulate in the worm's gut to initiate a defecation episode (R. B. Whitlatch, pers. comm.).

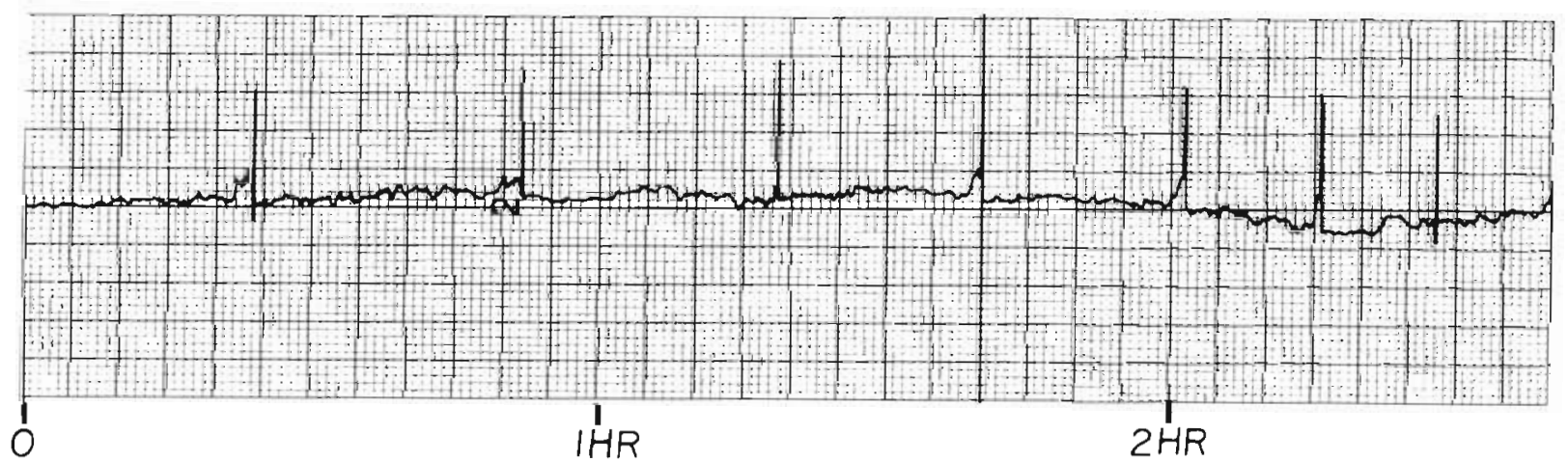

Fig. 2. Clymenella torquata. Representative defecation pattern. Each spike on the trace indicates a defecation episode. Total time shown is $2 \mathrm{~h} 40 \mathrm{~min}$ 
Table 1. Clymenella torquata. Effects of temperature on defecation activities. Defecation hour $=$ any hour during which one or more defecations occurred. Defecation activity period (DAP) = one or more consecutive defecation hours. Quiescence period $(\mathrm{QP})=$ one or more consecutive hours during which no defecations occurred. Where there were significant differences among temperatures, results of Duncan's multiple range test (DMRT) are shown; values represented by the same letter are not significantly different

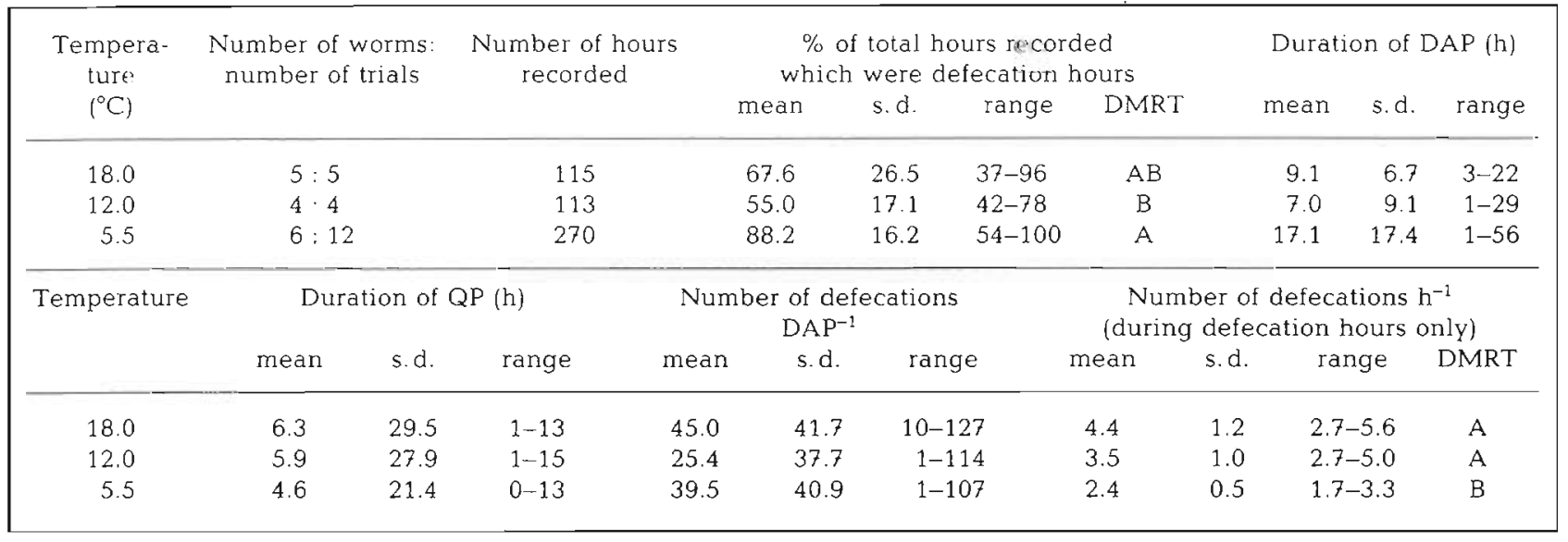

\section{DISCUSSION}

Except for a constant volume of sediment per defecation and the temperature effect on defecation rate, sediment reworking by Clymenella torquata may be characterized as highly variable. Considerable fluctuations in feeding activity, including temporary cessation, have been shown in other deposit feeders, e.g. a bivalve, Scrobicularia plana (Hughes, 1969); a polychaete, Pectinaria gouldii (Gordon, 1966); and a holothurain, Leptosynapta tenuis (Powell, 1977).

Results of this study were compared with previous investigations of Clymenella torquata feeding behavior (Table 2). At a mean annual water temperature of $11^{\circ} \mathrm{C}$, sediment turnover rates calculated by Rhoads (1967) and in this study differed by less than $9 \%$. Both of these exceeded, by more than two times, the rate determined by Mangum (1964a). Rhoads and the present study determined that $C$. torquata reworked $1 \mathrm{ml}$ of sediment worm ${ }^{-1} \mathrm{~d}^{-1}$ at 16 and $15.1^{\circ} \mathrm{C}$, respectively, while Mangum reported this rate at $26^{\circ} \mathrm{C}$. Disparity in defecation rate estimates extended to lower temperatures as well. Mangum measured a rate of $0.4 \mathrm{ml}$ worm ${ }^{-1} \mathrm{~d}^{-1}$ at $12.5^{\circ} \mathrm{C}$, approximately half the rate determined by Rhoads at $11{ }^{\circ} \mathrm{C}$ and the present study at $12.0^{\circ} \mathrm{C}$. Finally, the time interval between consecutive defecations observed by Mangum at $12.5^{\circ} \mathrm{C}$ was nearly the same as this investigation's interval at $5.5^{\circ} \mathrm{C}$.

Neither Mangum (1964a) nor Rhoads (1967) reported the size of worms they used; therefore, it is not clear whether the above differences in reworking rates reflect size disparities. However, mean lengths of the populations Mangum studied were reported in another paper (Mangum, 1964b), 4.1 and $5.2 \mathrm{~cm}$ for worms from Beaufort Harbor, North Carolina and West Haven, Connecticut, respectively. The worms used in the present study were approximately $5 \mathrm{~cm}$ long, so it seems that differences in worm size cannot account for the rate discrepancies. An alternative explanation may lie in the length of the pre-experimental acclimation period. Although not stated specifically, Mangum

Table 2. Comparison of selected results from 3 reworking studies of Clymenella torquata

\begin{tabular}{|c|c|c|c|c|c|}
\hline \multirow[t]{2}{*}{ Reference } & \multirow{2}{*}{$\begin{array}{l}\text { Estimated sediment turnover } \\
\text { rate at mean annual water } \\
\text { temperature of } 11^{\circ} \mathrm{C} \\
\left(\mathrm{ml} \text { worm }{ }^{-1} \mathrm{yr}^{-1}\right)\end{array}$} & \multirow{2}{*}{$\begin{array}{l}\text { Temperature at which } \\
\text { worm defecated } 1 \mathrm{ml} \text { of } \\
\text { sediment } \mathrm{d}^{-1}\end{array}$} & \multicolumn{3}{|c|}{$\begin{array}{c}\text { Interval between consecutive } \\
\text { defecations (min) }\end{array}$} \\
\hline & & & temperature & mean & range \\
\hline Mangum (1964a) & 136 & $26^{\circ} \mathrm{C}$ & $\begin{array}{l}26-28^{\circ} \mathrm{C} \\
12.5^{\circ} \mathrm{C}\end{array}$ & $\begin{array}{l}25 \\
26\end{array}$ & $\begin{array}{l}18-30 \\
18-60\end{array}$ \\
\hline Rhoads (1967) & 274 & $16^{\circ} \mathrm{C}$ & not reported & & \\
\hline Present study & 301 & $15.1^{\circ} \mathrm{C}$ & $\begin{array}{r}18.0^{\circ} \mathrm{C} \\
12.0^{\circ} \mathrm{C} \\
5.5^{\circ} \mathrm{C}\end{array}$ & $\begin{array}{l}14.5 \\
17.9 \\
26.3\end{array}$ & $\begin{array}{l}11-22 \\
12-22 \\
18-35\end{array}$ \\
\hline
\end{tabular}


(1964a) apparently collected worms and tested them soon after. In the present study, worms were acclimated to experimental conditions for at least 1 wh Another, functionally similar polychaete, Pectinaria koreni, increased its reworking rate over $8 \mathrm{~d}$ (Dobbs, in prep.) and this phenomenon has been qualitatively observed in $C$. torquata as well (pers. obs.).

Hot bead and hot wire anemometry have proven useful in monitoring irrigation (Scott et al., 1976; Gust and Harrison, 1981) and feeding behavior (this study) of infaunal organisms. The thermistor apparatus described here provides a detailed record of defecation episodes, as do other techniques (e.g. Wells, 1953; Mangum, 1964a; Kudenov, 1978), and offers distinct advantages. First, once microcosms are established, organisms are not subjected to pre-trial manipulation nor contact with monitoring equipment. Second, a closer approximation of environmental conditions can be achieved since the sensing thermistor can be positioned precisely to monitor a selected individual in a microcosm containing natural densities of infauna. Third, the system is maintenance-free for relatively long time periods. Fourth, the apparatus can be used to monitor activity of any organism which ejects feces, unconsolidated or pelletized, into the water immediately above the sediment surface (e.g. molpadanid holothurians and ampharetid polychaetes).

Acknowledgements. I thank S. Trombly for electronics craftsmanship and S. Feng, G. Taghon, V. Starczak, F. Streams, J. Weinberg, R. Whitlatch, R. Zajac, and an anonymous reviewer for critiques. I am especially grateful to $R$. Whitlatch for assistance in the preparation of this manuscript. This work was supported by The University of Connecticut's Research Foundation, a Grant-in-Aid of Reséarch from Sigma Xi, The Scientific Research Society of North America, and US Navy Contract Nos. 00140-77-C6536 and 00140-78-C6883.

\section{LITERATURE CITED}

Aller, R. C. (1980). Relationships of tube-dwelling benthos with sediment and overlying water chemistry. In: Tenore, K. R., Coull, B. C. (eds.) Marine benthic dynamics. University of South Carolina Press, Columbia, p. 285-308

Anderson, F. E. (1980). The variation in suspended-sediment and water properties in the flood-water front traversing the tidal flat. Estuaries 3: 28-37

Baumfalk, Y. A. (1979). Heterogeneous grain-size distribution in tidal-flat sediment caused by bioturbation activity of Arenicola marina (Polychaeta). Neth. J Sea Res. 13: $428-440$

Dobbs, F. C. (1981). Community ecology of a shallow subtidal sand flat, with emphasis on bioturbation by Clymenella torquata (Polychaeta: Maldanidae). M. S. thesis, University of Connecticut, Storrs

Eckman, J. E., Nowell, A. R. M., Jumars, P. A. (1981). Sediment destabilization by animal tubes. J. mar. Res. 39: 361-374

Goldhaber, M. B., Aller, R. C., Cochran, J. K., Rosenfeld, J. K., Martens, C. S., Berner, R. A. (1977). Sulfate reduction, diffusion, and bioturbation in Long Island Sound sediments: report of the FOAM group. Am. J. Sci. 277: 193-237

Gordon, D. C., Jr. (1966). The effects of the deposit-feeding polychaete Pectinaria gouldii on the intertidal sediments of Barnstable Harbor. Limnol. Oceanogr. 11: 327-332

Gust, G., Harrison, J. T. (1981). Biological pumps at the sediment-water interface: mechanistic evaluation of the alpheid shrimp Alpheus mackayi and its irrigation pattern. Mar. Biol. 64: 71-78

Hammond, L. S. (1981). An analysis of grain size modification in biogenic carbonate sediments by deposit-feeding holothurians and echinoids (Echinodermata). Limnol. Oceanogr. 26: 898-906

Hughes, R. N. (1969). A study of feeding in Scrobicularia plana. J. mar. biol. Ass. U. K. 49: 805-823

Kudenov, J. D. (1978). The feeding ecology of Axiothella rubrocincta (Johnson) (Polychaeta: Maldanidae). J. exp. mar. Biol. Ecol. 31: 209-221

LaBarbera, M. C., Vogel, S. (1976). An inexpensive thermistor flowmeter for açuatic biology. Limnol. Oceanogr. 21: $750-756$

Mangum, C. P. (1964a). Activity patterns in the metabolism and ecology of polychaetes. Comp. Biochem. Physiol. 11: 239-256

Mangum, C. P. (1964b). Studies on speciation in maldanid polychaetes of the North American Atlantic coast. II. Distribution and competitive interaction of five sympatric species. Limnol. Oceanogr. 9: 12-26

Nowell, A. R. M., Jumars, P. A., Eckman, J. E. (1981). Effects of biological activity on the entrainment of marine sediments. Mar. Geol. 42: 133-153

Powell, E. N. (1977). Particle size selection and sediment reworking in a funnel feeder, Leptosynapta tenuis (Holothuroidea, Synaptidae). Int. Revue ges. Hydrobiol. 62: $385-408$

Pryor, W. A. (1975). Biogenic sedimentation and alteration of argillaceous sediments in shallow marine environments. Geol. Soc. Am. Bull. 86: 1244-1254

Rhoads, D. C. (1967). Biogenic reworking of intertidal and subtidal sediments in Barnstable Harbor and Buzzards Bay, Massachusetts. J. Geol. 75: 461-476

Scott, D. M., Mazurkiewicz, M. Leeman, P. (1976). The longterm monitoring of ventilation rhythms of the polychaetous annelid Nereis virens Sars. Comp. Biochem. Physiol. 53A: 65-68

Wells, G. P. (1953). Defecation in relation to the spontaneous activity cycles of Arenicola marina L. J. mar. biol. Ass. U. K. 32: 51-63

Yingst, J. Y., Rhoads, D. C. (1978). Seafloor stability in central Long Island Sound 2. Biological interactions and their potential importance for seafloor erodibility. In: Wiley, $M$. (ed.) Estuarine interactions. Academic Press, New York, p. $245-260$ 